\title{
ARTIFÍCIOS DA INVENÇÃO MELÓDICA SEGUNDO JOHANN MATTHESON (1739)
}

\author{
DEVICES OF THE MELODIC INVENTION \\ ACCORDING TO JOHANN MATTHESON (1739)
}

Monica Isabel Lucas ${ }^{1}$

Universidade de São Paulo monicalucas@live.com 


\section{Resumo}

Entre os séculos XVI e XVIII, o mundo reformado luterano produziu textos que têm em comum o fato de emprestarem sistematicamente a terminologia derivada de retóricas e de poéticas clássicas para descrever fenômenos musicais. Certamente, a mais abrangente e detalhada dentre estas obras é aquela escrita por Johann Mattheson, intitulada Der vollkommene Capellmeister ("O mestre de capela perfeito"), publicada em 1739.

O presente artigo aborda o capítulo da obra de Mattheson dedicado à invenção melódica. Ele a descreve como a primeira parte de construção do discurso musical, discorre sobre suas partes e finalmente discute os lugares-comuns, fontes de argumentos para a invenção temática. Ao apresentar as ideias de Mattheson sobre a invenção, nossos objetivos, além de dar a conhecer o conteúdo do texto, são evidenciar a base retórica de seus escritos e defender a utilidade dos lugares-comuns como ferramentas para a composição musical nos séculos XVII e XVIII. Palavras-chave: Musica poetica; Mattheson; musical rhetoric; invention; Johann Mattheson; retórica musical; in- commonplaces. venção; lugares-comuns.

\section{Abstract}

Between the 16th and 18th Centuries, the reformed Lutheran world produced texts that have in common the systematical use of the terminology derived from classical rhetoric and poetics to describe musical phenomena. Certainly, the most comprehensive and detailed of these works is the writing by Johann Mattheson, entitled Der vollkommene Capellmeister ["The perfect master-of-chapel"], published in 1739.

This article deals with the chapter of Mattheson's work dedicated to melodic invention, described as the first part of the construction of musical discourse, presents its parts and finally discusses the commonplaces, sources of arguments for invention of musical themes. In presenting Mattheson's ideas about invention, we intend, in addition to making the content of the text known, to highlight the rhetorical basis of his writings and defend the utility of commonplaces as tools for musical composition in the 17th and 18th Centuries.

Keywords: Musica poetica; Johann

1 Possui Bacharelado Em Música pela Universidade de São Paulo (1990), Doutorado em Música pela Universidade Estadual de Campinas (2005) e Pós-Doutorado pela Universidade de São Paulo (2008). Especializou-se, como instrumentista (flauta-doce e clarinetes históricos) no Conservatório Real de Haia (Holanda). Atualmente ministra as disciplinas História da Música I e II e coordena o Conjunto de Música Antiga no Departamento de Música da ECA-USP. Como instrumentista, dedica-se aos clarinetes do século XVIII e à flauta-doce. Como pesquisadora, dedica-se ao estudo da concepção poético-retórica da música setecentista. É autora de "Humor e Agudeza em Joseph Haydn: os quartetos de cordas op. 33" (Annablume/Fapesp, 2008). 


\section{Musica Poetica}

Entre os séculos XVI e XVIII, o mundo reformado luterano produziu reflexões significativas sobre a relação entre música e linguagem, além de um enorme arcabouço teórico e prático para a composição, interpretação e análise musical. Estes textos têm em comum o fato de emprestarem sistematicamente a terminologia derivada de retóricas e de poéticas clássicas para descrever fenômenos puramente musicais.

Nos domínios luteranos, diferentemente do que ocorreu no mundo contrarreformado, a música tornou-se um importante objeto de estudo prático nas escolas, a partir da reforma do ensino consolidada em 1528 por Philipp Melanchton. É sabido que as escolas luteranas constituíram uma relevante via de transmissão do dogma luterano. Mas elas foram, ao mesmo tempo, importante veículo de estudos humanistas no mundo reformado. As preceptivas musicais concebidas para este uso escolar são manuais práticos de solmização e contraponto, cuja finalidade era a de proporcionar aos alunos o domínio técnico que os habilitasse a prover música prática para os serviços religiosos.

Neste contexto, surge, nas preceptivas musicais luteranas, uma nova compreensão no conceito de música, que se soma às categorias medievais da musica theorica e musica practica: musica poetica, ou composição musical. Esta designação dá título a diversas preceptivas musicais, como aquelas de Heinrich Faber (Musica poetica, 1548), Gallus Dressler (Praecepta musicae poeticae, 1564), Joachim Burmeister (Musica poetica, 1606), Andreas Herbst (Musica poëtica, 1644) e Franz Murschhauser (Academia musico-poetica, 1721). A ideia do afeto como princípio unificador de música e palavra fundamenta, nestas obras, o uso de termos advindos de retóricas ciceronianas para designar procedimentos musicais. No século XVIII, muitas destas preceptivas passaram a ser acompanhadas de uma extensa discussão teórica, como se lê em autores como Heinichen, Mattheson e Forkel.

Sem dúvida, a exposição mais abrangente e detalhada, dentre as obras que perfazem a instituição da musica poetica, é representada pelos escritos de Johann Mattheson, compositor, escritor e diplomata que viveu em Hamburgo entre 1681 e 1764. Dentre suas obras, destacam-se três escritos de juventude: Das Neu-eröffnete Orchestre ("A Orquestra recém-inaugurada", 1713), Das Beschützte Orchestre ("A orquestra protegida", 1717), Das Forschende Orchestre ("A orquestra investigativa", 1721] e um escrito tardio, Der vollkommene Capellmeister ("O mestre de capela perfeito", 1739). Destas, a última é a mais extensa e profunda, tendo tido grande relevância para o pensamento musical posterior a Mattheson. Ela foi apontada no próprio século XVIII como obra indispensável a uma biblioteca musical completa (HILLER, 1768, p.3) e estava presente nos acervos pessoais de compositores como Haydn e Beethoven. Mattheson foi o primeiro autor a apresentar um sistema retórico-musical abrangente, que inclui discussões de natureza poética. A metáfora da música instrumental como "discurso dos sons", por ele cunhada, foi muito utilizada por pensadores posteriores a ele. A obra pode seguramente ser considerada o maior monumento da musica poetica. 
A semelhança entre os conteúdos dos manuais de oratória latinos e aqueles exibidos nas obras de Mattheson é evidente e tem sido reiteradamente discutida, ${ }^{2}$ e a proposta de que Der vollkommene Capellmeister emule ideais ciceronianos é reforçada pelo fato de Mattheson ter destinado suas poéticas musicais a um público versado na leitura dos clássicos que, como ele, frequentava os círculos humanistas de Hamburgo. O próprio Mattheson declara, como destinatário de suas obras, o galant homme, o cortesão naturalmente educado que conhece os protocolos de circunstância, tempo e lugar da corte, e, com isto, sabe sempre agradar a seus interlocutores, como se lê nos títulos de seus escritos:

A ORQUESTRA recém-inaugurada / ou instrução universal sobre / como um Galant-homme pode alcançar uma compreensão perfeita da elevação e da dignidade da nobre música / para formar seu Gout através dela, / entender os Terminos technicos e razonar adequadamente sobre esta admirável ciência. Hamburgo, $1713 .{ }^{3}$ (grifo meu).

A ORQUESTRA protegida [...] em que não apenas o verdadeiro Galant-homme, que não exerce esta profissão, mas também muitos dos próprios músicos podem formar o conceito mais claro e verdadeiro sobre a ciência musical / habilmente depurado da poeira escolar / comunicado / e colocado verdadeira e propriamente. Hamburgo, $1717 .{ }^{4}$ (grifo meu).

"O mestre de capela perfeito" divide-se em três partes, sendo a primeira predominantemente teórica, ao passo que a segunda e a terceira abordam prioritariamente a sistemática da composição a partir da orientação retórica: a segunda parte dedica-se à invenção e disposição, ao passo que a terceira se concentra na elocução e na pronunciação, acrescidas de um capítulo final envolvendo o juízo crítico na escuta musical.

O presente artigo aborda o capítulo 4 da segunda parte do tratado, intitulado "Sobre a invenção melódica". Nele, Mattheson apresenta a invenção como a primeira parte de construção do discurso musical, discorre sobre suas partes e finalmente discute os lugares-comuns, fontes de argumentos para a invenção temática transpostos da Lógica e da Retórica. Ao apresentar as ideias de Mattheson, nosso objetivo, além de dar a conhecer o conteúdo do texto, é evidenciar a base retórica de seus escritos e sua fundamentação em proposições ciceronianas, além de defender a utilidade dos lugares-comuns para a composição musical nos séculos XVII e XVIII.

2 Na vasta lista de autores que discorrem sobre este assunto, vale mencionar os escritos de Schering (1908), Unger (1941), Dammann (1968), Bartel (1997), Braunschweig (2001) e Barros (2019).

3 Original: "Neu-eröffnete ORCHESTER/oder universelle und gründliche Anleitung/ wie ein Galant-Homme eine volkommenen Begriff von der Hoheit und Würde der edlen Music Erlangen/ seinen Gout darnach formieren/ die Terminos technicos verstehen und geschicklich von dieser vortrefflichen Wissenschafft raisonnieren möge (Hamburg, 1713)".

4 Original: "Die Beschützte orchestra [...] Worin nicht nur einem würcklichen gallant-homme, der eben kein Porofessions-Verwandter, sondern auch manchen Musico selbst die alleraufrichtigste und deutlichste Vorstellung musicalischer Wissenschafften/ wie sich dieselbe vom Schulstaub tüchtig gesäubert/ eigentlich und wahrhafftig verhalten/ ertheilet (Hamburg, 1717)". 


\section{Invenção}

Retóricas e poéticas humanistas reafirmam as noções advindas de oratórias latinas, segundo as quais a invenção (inventio) é considerada o primeiro dentre os cinco estágios do processo da composição de discursos (partes oratoriae). Cícero, em De oratore, afirma:

Toda arte oratória está dividida em 5 partes: em primeiro lugar, o orador deve inventar o que vai dizer; em segundo, ordenar, pesar e compor o inventado; em terceiro vestir e adornar o discurso; em quarto, guardá-lo na memória; em quinto, recitá-lo com dignidade e graça. ${ }^{5}$ (2009 [46 a.C.], I, 142, p.170, trad. A. Scatolin).

Em De Inventione, tratado de juventude de Cícero, encontra-se a passagem, igualmente transcrita na retórica anônima dedicada a Herênio:

A matéria da arte retórica é aquela aprovada por Aristóteles [a descoberta de argumentos verossímeis aptos a persuadir]. Suas partes são invenção [inventio], disposição [dispositio], elocução [elocutio], memorização [memoria], pronunciação [pronuntiatio]. ${ }^{6}$ ([CíCERO], 1995 [c. 90 a.C.]. I, 7, 9, p. 19, trad A. Seabra).

Nesses mesmos dois textos, segue-se uma breve definição das partes mencionadas:

Invenção é a descoberta de argumentos verdadeiros ou verossímeis que tornem a causa provável. Disposição é a distribuição dos argumentos descobertos em ordem adequada. Locução é acomodar a linguagem aos argumentos descobertos. Memória é a retenção mental firme da matéria e das palavras. Pronúncia é o controle da voz e do corpo de modo adequado à matéria e às palavras. ${ }^{7}$ ([CíCERO], 1995 [c. 90 a.C.]. I, 7, 9, p. 21).

Dentre essas cinco partes, a invenção é considerada, por Cícero, assim como por teóricos humanistas que emulam as retóricas latinas, a parte mais importante do processo de composição poética. A invenção é descrita como "a alma da poesia" (Giason Denores, comentário à Poética, 1553), como o "esqueleto que sustenta o corpo" (Giraldi Cinthio, 1554). Pierre Ronsard (1565) afirma que a invenção é a "Mãe de todas as coisas" e escreve que as outras etapas da composição "seguem a invenção como a sombra acompanha o corpo". Christian Friedrich Hunold, conhecido de Mattheson, afirma, semelhantemente, que "a invenção é a alma; a disposição é o corpo da poesia; e os versos e rimas são, por assim dizer, apenas uma roupagem elegante"8 (HUNOLD, 1722, IV, II, p.540).

$5 \quad$ Original: "Cumque esset omnis orationis vis ac facultas in quinque partes distributa, ut devbere reperire primum quid diceret, deinde inventa non solum ordine, sed etiam momento quodam atque iudicium dispensare atque componere, tum ea denique vestire atque ornare oratione post memoria saepire; ad extremum agere cum dignitate et venustate".

6 Original: "Quaere matéria quidem nobis rhetoricae videtur artis ea quam Aristoteli visam esse diximus; partes autem eae quas pelrique dixerunt, inventio, dispositivo, elocutio. Memoria, pronunciatio".

7 Original: "Inventio est excogigatio rerum verarum aut veri similium quae causam probabilim reddant; dispsitio est rerum inventarum in ordinem distributivo; elocutio est idoneorum verborum ad inventionem accommodatio; memoria est firma animi rerum ac verborum perceptivo; pronuntiatio est ex rerum et verborum dignitate vocis et corporis moderatio".

8 Original: "Inzwischen ist die Invention das Hauptstücke der ganzen Poesie. Die Invention is die Seele, die Disposition der Leib von einem Gedichte, die Verse und Reime sind gleichsam nur eine zierliche Kleidung". 
No Dicionário Latino-Português de Francisco Saraiva, o verbo latino invenire tem por sinônimos "encontrar, descobrir, confrontar-se com" (SARAIVA, 2000 [1881], p.633).

Raphael Bluteau, em seu Diccionário Latino-Portuguez, publicado entre 1712 e 1728, dá quatro acepções ao termo "invençam":

1. O excogitar algum artificio, \& cousa nova [...]. Verdadeiras invençõens são as que Deos revela; que as dos homens, são observaçõens de cousas naturais, e interferências fundadas nelas; v.g. a Pintura, a Optica nas sombras, \& reflexos da luz, os relogios de Sol nas sombras das árvores, a Impressão nos riscos, \& sinaes, gravados da natureza em pedras. Invenção: cousa inventada com arte.

\section{Cousa ficticiamente inventada.}

3. A arte de achar alguma coisa desviada, oculta, ou perdida: "ao Lecenciado Gaspar Alves se deve a Invenção desta carta".

4. A primeira das cinco partes da Rhetorica, que consiste em inventar argumentos verdadeiros, ou verossímeis para a probabilidade da matéria em que se fala. (BLUTEAU, 1713, v.4, p.181).

Desta forma, invenção, para Bluteau, inclui tanto as ideias obtidas por revelação divina quanto aquelas decorrentes da observação da natureza. Contempla, ainda, o senti- do que se aproxima da acepção moderna, "criar algo novo, imaginar algo irreal" (INVENÇÃO, s.d., on-line), além da ideia de encontramento ou descoberta. Finalmente, quando aplicada especificamente à retórica, Bluteau recupera a noção ciceroniana, referindo-se a recuperar, a partir de um repositório preconcebido, argumentos que, por verdade ou verossimilhança, sejam persuasivos. É interessante notar que léxicos modernos, como o Caldas Aulete, ainda mantenham a definição da invenção como uma das partes da retórica. Nesses textos, fica claro que invenção descreve tanto uma habilidade, seja ela natural (sentido em que se aproxima de termos como imaginação ou engenho) ou forjada pela técnica, quanto seu resultado ou efeito.

O uso retórico do termo invenção domina seu emprego nas poéticas clássicas e em suas emulações humanistas. Nesses textos, inventio, em sentido técnico, é a denominação dada ao achamento dos pensamentos e das possibilidades argumentativas a serem desenvolvidas a partir de um tema ou de uma questão. Refere-se, assim, à apreciação das circunstâncias que se relacionam à matéria tratada. A etapa da inventio implica obter uma visão geral, percebendo, entendendo e julgando o assunto apresentado, de modo a descobrir argumentos que favoreçam uma causa, ampliando, adornando e exagerando os pontos bons, de modo que estes sobrepujem os pontos maus, dos quais se deve evitar tratar, como afirma Cícero em De oratore (I, p.143).

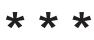

Nas poéticas musicais, a invenção passa a ser matéria de discussão apenas no século XVIII. Considerando que preceptivas dos séculos XVI e XVII discorrem prioritaria- 
mente sobre a composição da música vocal, é plausível supor que esta lacuna se deva ao fato de que a invenção, para estes autores, já esteja previamente dada pelo texto, pertencendo, assim, ao âmbito das letras, e não àquele da composição musical. No século XVIII, discussões como as de Mattheson ou Scheibe, que surgem no contexto das discussões sobre música instrumental, trazem informações relevantes sobre esta etapa do processo composicional.

Em "A orquestra recém-inaugurada", de 1713, Mattheson estabelece a divisão de partes do discurso já proposta por retóricas clássicas: "Três coisas pertencem à composição: Inventio (a invenção), Elaboratio (a elaboração), Excecutio (a realização ou apresentação), que evidenciam um parentesco bastante próximo com a oratória ou retórica (arte de discursar)"9 (MATTHESON, 1713, II, 1, 3, p.104). ${ }^{10}$

No capítulo dedicado à invenção em "O mestre de capela perfeito", Mattheson (1713, II, 4, 13, p. 132) reitera a divisão ciceroniana: "A arte [da invenção] deverá ter três companheiras inseparáveis [...]. elas se chamam dispositio, elaboratio \& decoratio-isto é, a disposição adequada, a elaboração diligente e a ornamentação engenhosa da obra melódica". ${ }^{11}$

Nesse contexto, declaradamente retórico, deve ser entendida a definição de invenção que Mattheson recupera de Giovanni Battista Doni (1593-1647): "[...] uma imaginação [Ersinnung] ou um excogitar [Erdenckung] de cantos que agradam ao ouvido"12 (MATTHESON, 1713, II, 4, 2, p.121).

Barros lembra que a eufonia - ou, como diz Doni, a construção de "cantos que agradam ao ouvido" - constitui, também para oradores, por exemplo Quintiliano (IX, 4, 116), o mais importante critério de juízo da composição: "[...] ainda que a razão auxilie no processo da composição, seu melhor juiz é o ouvido, pois é pelo prazer dele que o processo se orienta" (apud BARROS, 2011, p.8).

É interessante comparar a definição de Mattheson com aquela proposta por Johann Adolf Scheibe, que não apenas compartilhou dos mesmos círculos sociais de Mattheson em Hamburgo, mas ainda atuou como compositor e autor de textos teóricos. O tratamento da invenção musical pelo autor dinamarquês encontra-se disposto em três artigos publicados em Der Critische Musicus ("O músico crítico"), revista editada pelo próprio Scheibe em Hamburgo em 1737, ou seja, dois anos antes da publicação de "O mestre de capela perfeito". No primeiro artigo lemos que

Entende-se propriamente por invenção musical, uma habilidade [fertige Eigenschaft] do espírito em expressar uma aptidão inata para apresentar uma matéria de maneira organizada, coerente e fogosa, de acordo com suas características. Pode-se dizer também que é uma habilidade do compositor para pensar musicalmente de maneira coerente, e conceber a disposição de uma peça de acordo com uma qualidade específica do espírito e com uma capacidade rigorosa de

9 Original: "Es gehören sonst zur Composition dreyerley: Inventio (Die Erfindug), Elaboratio (Die Ausarbeitung), Excecutio (Die Ausführung oder Aufführung) welches eine ziemliche nahe Verwandschaft mit der Oratorie oder Retorique (Rede-Kunst) an den Tag leget".

10 Todas as traduções do alemão são minhas.

11 Original: "Dieselbe [die Erfindungkunst] hat drey unzertrennliche Gefährten [...] Diese drey heissen: Dispositio, Elaboratio \& Decoratio, d.i. die geschickte Einrichtung, fleissige Ausarbeitung und gescheute Schmüickung des melodischen Wercks". 
julgamento. Conclui-se que ela refere tanto à grandeza de alma quanto ao conhecimento profundo das ciências que pertencem à música. Pela última o espírito alcança a necessária e rigorosa reflexão. ${ }^{13}$ (SCHEIBE, 1738, VIII, p.59).

A definição apresentada por Scheibe se ampara seguramente em "Do Sublime" (Peri Hypsos), obra provavelmente composta no século I e de autoria duvidosa, atribuída a Dionísio Longino, que voltou a ter grande circulação na Europa a partir de sua tradução por Nicholas Boileau (1674), penetrando, a partir de Edmund Burke (1757) e Emmanuel Kant (1764), definitivamente na história da estética ocidental. Scheibe descreve a invenção conforme apresentada pelo autor de "O Sublime", que afirma que a primeira fonte para conceber ideias extraordinárias é justamente aquela mencionada por Scheibe: grandeza de alma. Esta ligação claramente apresentada entre Scheibe e Longino está apenas indicada em Mattheson. Ao tratar da invenção, Scheibe se concentra apenas nas suas fontes naturais, sem se deter nas causas artificiais, que também são descritas, embora com menor ênfase, por Longino. Para Mattheson, diferente do que ocorre com Scheibe, o foco da invenção é o seu viés técnico e sua sistematização mediante o auxílio dos lugares-comuns.

A dupla acepção da invenção como uma confluência entre natureza e arte está presente também em Iconologia, célebre coleção de emblemas da autoria de Cesare Ripa, que recebe, na versão inglesa de 1709, o título Iconologia, or Moral Emblems. Nela, "invenção" recebe a seguinte figura (corpo), acompanhada de sua explicação (alma):

Esta senhora das artes aparece em um vestido branco, no qual se inscreve NON ALIUNDE; duas pequenas asas em sua cabeça; em uma mão, a imagem da natureza, uma pulseira na outra com o moto AD OPERAM. A juventude denota os muitos espíritos no cérebro, onde a invenção se forma; o vestido branco, sua pureza, não usando o labor de outros homens, como mostra o moto. As asas, a elevação do intelecto; os braços nus, o fato de estar sempre em ação, a vida da invenção. A imagem da natureza mostra sua invenção. ${ }^{14}$ (RIPA, 1709, p. 43, tradução minha).

\footnotetext{
13 Original: "Wir verstehen eingentlich unter der musicalischen Erfindung, eine fertige Eigenschaft des Geistes, wodurch wir die angebohrne Geschicklichteit zur Music nach der Beschaffenheit der Dinge ordentlich, vernunftig und feurig an den Tag legen. Man kann auch sagen, dass sie eine Eigenschafft des Componisten ist, auf vernunftige Art, musicalisch zu denken und die Einrichtung eines Stückes nach einer gefunden Fähigkeit des Geistes, und nach einer gründlichen Urtheilungskraft, zu entwerfen. Hieraus ist zu schliessen, das es auf die grösse des Geistes, und dann ferner auf eine wolgegründete Käntniss der zur Music gehörigen Wissenschaften ankommt. Durch das letzte erlangt der Geist eine nöthige und sichere Überlegung".

14 Original: "Inventione: INVENTION. This Mistress of Arts appears in a White Robe, whereon is written, NON ALIUNDE; to little Wings on her Head; in one Hand, the Image of Nature, a Cuff on the other, with the Motto, AD OPERAM. Youth denotes many Spirits in the Brain, where Invention is form 'd; the White Robe, the Pureness of it, not making Use of other Mens Invention, as the Motto shews. The Wings, Elevation of Intellect; naked Arms, her being ever in Action, the Life of Invention. The Image of Nature shews her Invention".
} 


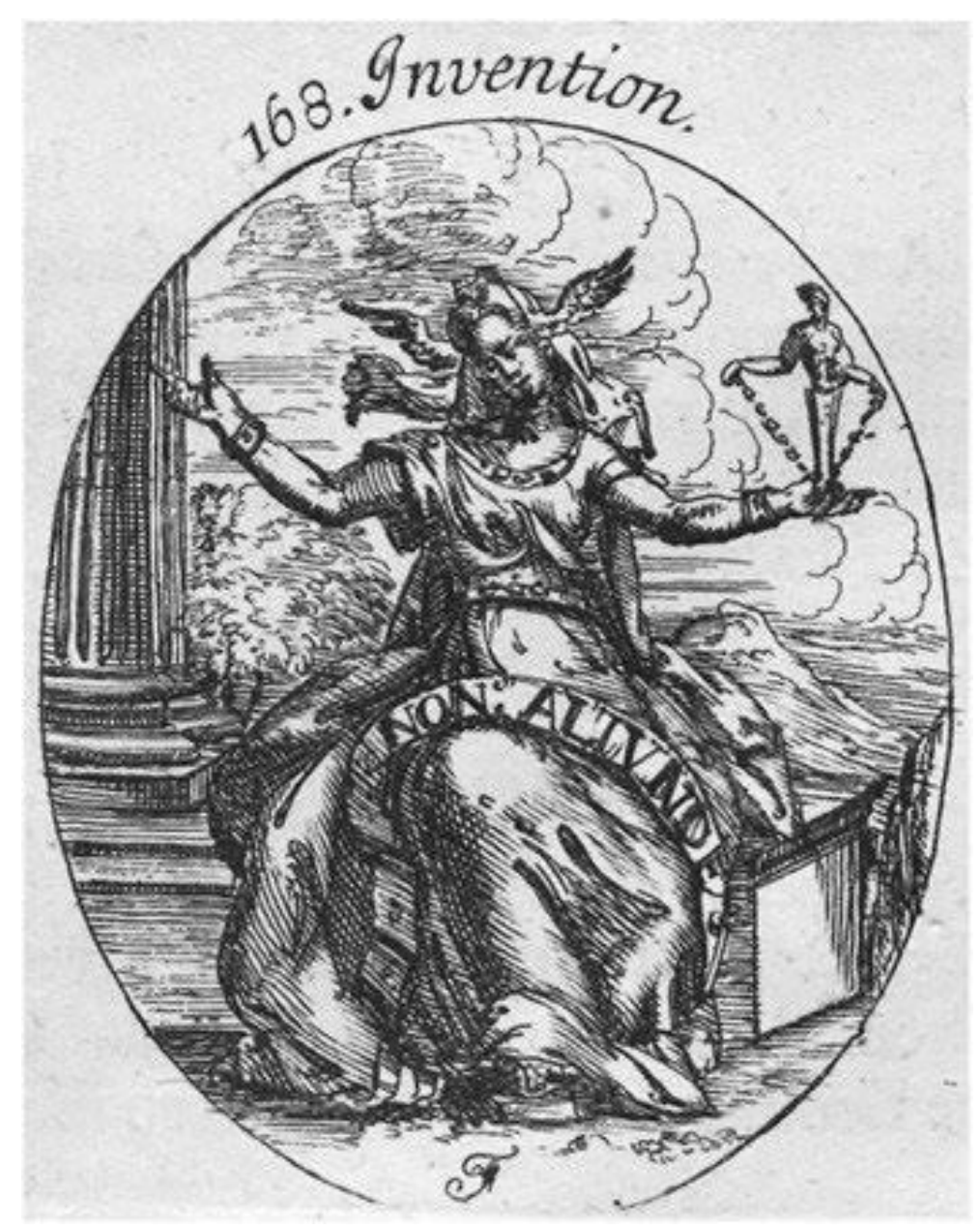

Fig. 1: Invenção. Fonte: Ripa (1709, p.43).

Bluteau (1638-1734) pode ter conhecido esta publicação inglesa de Ripa, especialmente considerando o fato de ter nascido em Londres, onde residiu até 1648 . No verbete "invençam" de seu dicionário, ele apresenta uma imagem muito semelhante:

Pintase a invenção com azas, \& vestida de branco, com o mote Non aliunde, ou (segundo os egypcios), Proprio Marte. Nas azas se significa o elevado da potencia intelectiva, que a produz; a brancura do vestido denota a clareza, \& verdade com que há de obrar, \& nas letras se ve, que há de ser própria, \& não de empréstimo, \& alheia. (BLUTEAU, 1713, v.4, p.181).

Nas duas representações, aquela de Ripa e a proposta por Bluteau, aparece a oposição que trata da invenção, por um lado, como resultante da imaginação criativa, advinda de furor poético ou de revelação divina (non aliunde) complementada, por outro lado, por uma concepção técnica, que trata a invenção como resultado do exercício da razão. O vestido branco, que em ambos os autores contempla as ideias de pureza e clareza, refere-se seguramente à acepção criativa do termo (Ripa indica, pela brancura, o fato de a invenção se apoiar em ideias próprias, e não alheias). Ambos os autores empregam as asas como signo de engenho, agilidade intelectual que também constitui requisito natural para a invenção. Os braços nus, em Ripa, entretanto, apresentam a invenção como um processo decorrente do trabalho intelectual. Na mesma chave 
se inserem os motos ad operam, em Ripa, e proprio Marte, em Bluteau. Ao passo que Ripa enfatiza o trabalho (opera) em si, Bluteau se concentra na agudeza, utilizando o exemplo da invenção do escudo, artefato alegadamente inventado por Marte, Deus da Guerra, a partir da observação da natureza.

Ao dedicar-se à causa formal da invenção, Mattheson apresenta já suas causas eficientes, a natureza e a arte. A oposição entre esses dois âmbitos aparece em diversos pontos das preceptivas retóricas, sendo especialmente empregado na discussão sobre o orador perfeito e sobre a invenção. Este lugar-comum também aparece em "Sobre a invenção melódica"; no entanto, sua discussão extrapolaria o âmbito do presente artigo. ${ }^{15} \mathrm{Em}$ "O mestre de capela perfeito" Mattheson se concentra na invenção como técnica para a composição de temas musicais.

\section{Partes da invenção}

Mattheson divide a inventio em três elementos principais: modo (modus), mensuração (tactus) e tema (thema). A analogia entre estes três elementos e os três tipos de provas persuasivas já fornecidas pela retórica aristotélica e retomada pelas preceptivas latinas salta imediatamente aos olhos. Nesse sentido, a eleição temática corresponderia à descoberta de provas lógicas, ao passo que a escolha do modus se relacionaria aos argumentos afetivos, e a eleição da mensuração seria aproximada - ainda que não de modo explicitamente declarado por Mattheson, como veremos - ao caráter.

Ao discorrer sobre os modos, Mattheson convida o leitor à investigação de outras fontes, dentre as quais se encontra Das Neu-eröffnete Orchestre ("A orquestra recém-inaugurada"), também de sua autoria, publicado em 1713. Nesse texto de juventude, ele recorre a uma definição de Athanasius Kircher (1650): "[...] modo é uma certa razão que forma a concórdia da música. Aquilo que o canto seria sem o modo é o mesmo que o silogismo seria sem a figura"16 (MATTHESON, 2004 [1713], I, 14, p.58).

Ele refere o leitor, ainda, à leitura do referencial dicionário musical de Sebastién de Brossard (1703), em que lemos que "o modo musical é uma maneira de iniciar um canto, conduzi-lo dentro de certos limites e encerrá-lo adequadamente; consiste em se servir sobretudo e mais frequentemente de algumas notas do que de outras" (BROSSARD, 1703, s.p.).

Para além da analogia discursiva apresentada por Kircher, fica clara a posição do modo como categoria ontologicamente anterior à elaboração do tema. Em seu referencial texto de 1739, Mattheson não se aprofunda nas questões que envolvem a tonalidade (ou do modo, em composições de estilo antigo). O capítulo "Sobre a propriedade dos tons e seu efeito na expressão dos afetos" (III, 2, p.231-253) do texto de 1713 descreve tecnicamente os modos gregos, assim como os modos medievais. Contudo, como matéria de invenção, interessa-nos especificamente a extensa discussão que Mattheson apresenta na terceira parte deste tratado de juventude, acerca dos efeitos dos modos:

\footnotetext{
15 Para uma discussão sobre o papel da natureza e da arte em "Sobre a invenção melódica", cf. Lucas (2016).

16 Original: "Modus est autem certa quaedam Musici concentus formandi ratio \&, qui cantum fecerit, sine certo modo, is Syllogismum fecerit sine figura".
} 
O fato de cada tonalidade ter algo especial em si e se diferenciar de outra por provocar efeitos muito diferentes é do conhecimento de todos - se considerarmos a época, as circunstâncias e as pessoas. ${ }^{17}$ (2004 [1713], III, 2, 2, p.232).

Nesta parte, Mattheson apresenta uma conhecida discussão sobre as potencialidades afetivas dos modos eclesiásticos e das tonalidades. Esta apresentação se insere em uma rica tradição musical que tem raízes na Antiguidade e se prolifera em poéticas musicais surgidas entre o fim do século XVII e a metade do século XIX. ${ }^{18}$ Estas correlações entre tonalidades e afetos se baseiam em critérios como a observação das possibilidades de colorido conferidas pela instrumentação ou as sutilezas de afinação conferidas pelos temperamentos desiguais.

Vale notar que não há conformidade entre os autores que se dedicaram ao tema, no que tange às capacidades afetivas das tonalidades. O próprio Mattheson está ciente desta disparidade, ao afirmar que "há muitas contradições quanto aos afetos que cada tonalidade desencadeia, quais são eles e como são"19 (2004 [1713], III, 2, p.232).

Não obstante esta diversidade, que frequentemente envolve contradições extremas entre as definições, o que nos importa observar é a existência de uma opinião comumente aceita nos séculos XVII e XVIII, segundo a qual as tonalidades encerram em si potencialidades afetivas, e que, desta forma, a escolha do tom está longe de ser fortuita, devendo estar em harmonia com o afeto principal exibido pelo tema da composição, que dela decorre.

A questão da mensuração (tactus) é mais pormenorizadamente discutida por Mattheson em "A Orquestra recém-inaugurada" (1713, I, 3, p.76-89) e também em "O mestre de capela perfeito" (1739, II, 6 e 7, p.160-174). Ao tratar dos ritmos, Mattheson divide o assunto em dois tópicos, designados respectivamente como rhytmopoeia e rhytmica. A rhythmopoeia (assunto do capítulo II, 6 de "O mestre de capela perfeito") discorre sobre as características técnicas e sobre o potencial emotivo dos pés métricos. Neste capítulo encontramos definições do tipo:

O [pé métrico] espondeu consiste em dois sons igualmente longos. Tem a supremacia dentre todos os outros ritmos, não apenas por ser elevado e sério, mas por ser fácil de compreender. Esta observação dá lugar a uma boa invenção, se quisermos escrever algo introspectivo, sério, elevado e fácil de se compreender. ${ }^{20}$ (MATTHESON, 1991 [1739], II, 6, 7, p.164).

A relação entre duração das notas (curta/longa) está submetida a uma ordem mais ampla, que Mattheson denomina rhythmica. Este assunto está desenvolvido tanto no

\footnotetext{
17 Original: "Dass nun ein jeder Tohn etwas sonderliches an sich habe / und sie in den Effect einer von dem andern sehr unterschieden sind / ist wol einmahl gewiss / wenn man Zeit / Umstände und Personen dabey wol consideriret [...]".

18 Para uma discussão mais ampla sobre o assunto, cf. Steblin (2005).

19 Original: "[...] was aber ein jeder Tohn eigentlich vor Affecten, wie und wenn er selbige rege mache / darüber gibt es viel Contradicirens".

20 Original: "Der Spondäus, welcher aus zween gleich-langen Klängen bestehet, hat billig unter allen rhythmis der Ober-Stelle, nicht nur wegen seines ehebaren und ernsthafften Ganges; sondern auch weil er leicht zu begreiffen ist. Diese Anmerckung gäbe schon Anlass zu einer guten Erfindung, wenn man etwas andächtiges ernsthafftes, ehrebietiges und dabey leichgbegreiffliches setzen wollte".
} 
capítulo seguinte de "O mestre de capela perfeito" (II, 7) quanto no texto de 1713 - texto ao qual Mattheson remete seu leitor em seu escrito tardio.

Em "A orquestra recém-inaugurada" (1713), Mattheson descarta as relações entre as durações das notas que perfazem a rhythmopoeia e se concentra no andamento ("o lento e o ágil") e na acentuação ("o bater do tempo"), definida, segundo Mattheson, identicamente pelos termos Zeitmass, Battuta, Tactus e Mesure (2004 [1713], I, 3, 2, p.76-77). Vale notar que esta acepção, que traduzimos para o português como "mensuração", é aquela que corresponde ao termo tactus no capítulo sobre a invenção. Procedendo da mesma maneira que ocorre com os pés métricos, Mattheson aborda a mensuração de acordo com suas características técnicas e seus efeitos na alma, com descrições do tipo:

6/4 tem 6 semínimas, que são divididas em duas partes por thesis e arsis, de modo que o tempo forte recebe 3 tempos e o fraco, idem. É a mensura das coisas sérias, in specie, contudo, também é usada em gigas graves, que denominamos loure. ${ }^{21}$ (2004 [1713], III, 8, p.171).

No escrito de 1739, Mattheson vai além da discussão de 1713, acrescentando à rhythmopoeia um segundo elemento, que ele denomina le mouvement, ou o movimento (die Bewegung). Ele afirma que, entre os italianos, não existe um termo que designe o conceito: "[eles] qualificam [le mouvement] com epítetos, como affettuoso, con discrezione, col spirito etc., de modo que se pode dizer destes sinais que são mais subentendidos que escritos" (II, 7, 7, p.171). Mattheson explica que a finalidade da mensuração é lograr o mouvement, ou seja, a comoção da alma.

A mensuração é um caminho cujo fim é o movimento. Assim como devemos diferenciar o caminho e o fim a que ele conduz, também devemos diferenciar mensuração e movimento. E assim como a voz ou o canto deve se guiar pela mensuração, o compasso é conduzido e avivado pelo movimento. ${ }^{22}$ (1991 [1739], II, 7, 24, p.173).

Sendo assim, percebemos que, assim como já ocorre no tratamento dos modos, o ritmo, como matéria de invenção, interessa a Mattheson na medida em que nele se percebe um potencial para comover o ouvinte e que envolve desde as menores partes (relação entre notas breves e longas) até as relações de andamento e acentuação.

Mattheson deixa isto claro em duas passagens do capítulo sobre a rítmica (II, 7): "O compasso [Tact], segundo o dizer comum, tem sua origem no sentimento (a tactu)" (II, 7,2, p.171). Ele reitera a ideia no inciso seguinte, ao afirmar que "nenhuma melodia terá poder para suscitar uma emoção (Empfindung) verdadeira ou um sentimento (Gefühl)

\footnotetext{
21 Original: "6/4 zeiget sechs viertel als so viel Membra des Tacts an / welche per thesin \& arsin in zwey gleiche Theile gehen / so dass der Niederschlag 3. und der Auffschleg even so viel bekommt. Es wird diese Mensur zu serieusen Sachen / in specie aber zu den gravitäschischen Giquen, die man Louren nennet/ gebrauchet".

22 Original: "Die Mensur ist ein Weg; dessen Ende aber die Bewegung. Gleichwie nun ein Unterschied zu machen ist zwischen dem Wege selbst, und dem Ende dahin der Weg führet: also ist auch ein Unterschied zwischen Mensur und Mouvement. Und wie die Stimme oder der Gesang sich von der Mensur muss lernen lassen, also wird hinwiederum der Tact von der Bewegung geführet und belebet".
} 
se os pés métricos não estiverem organizados pela rythmica de modo a terem proporção agradável entre si e em relação uns aos outros"23 (1991 [1739], II, 7, 3, p.171).

Sendo assim, no tratamento da mensuração (tactus) como uma das três partes constituintes da invenção melódica, o ritmo deve ser entendido não apenas por suas características técnicas, mas por seu potencial persuasivo.

Mattheson, em 1739, discorre sobre os pés métricos a partir de seu caráter, entendido como uma disposição de alma duradoura. Ele os qualifica com termos como "elevado", "moderado", "majestoso" etc. O mesmo ocorre com os compassos, no texto de 1713: quando explicados de acordo com o mouvement, "os movimentos da alma ou do bom gosto", os mesmos são qualificados com termos que representam caracteres, como "grave”, "lento", “adagio", vivace”. Dessa forma, embora a relação entre ritmo e caráter não seja formalmente declarada, as definições exibem, na prática, esta proximidade.

É interessante lembrar que, no tratamento sobre a mensuração, Mattheson a relaciona às fórmulas definidoras das diversas espécies de danças. No âmbito das danças, essenciais ao gosto francês setecentista, a relação entre o ritmo e a noção de caráter é evidente pelo menos desde o século XVII. As danças instrumentais dos principais clavecinistes franceses, desde Louis Couperin (1626-1661) até Jean-Philippe Rameau (1683-1764), são costumeiramente batizadas com nomes de personagens ou de localidades, o que não apenas serve como homenagem, mas principalmente como indicativo do caráter da peça. A relação entre as ideias de dança e caráter aparece, ainda, no título de peças como colagem realizada por Jean-Fery Rébel intitulada Les caractères de la danse (1715).

Ao discorrer sobre o gênero das danças no texto de 1739, Mattheson também deixa transparecer a mesma relação entre ritmo e caráter: "A utilidade da arte da dança e de suas melodias consiste em, através delas, criar o ódio a certos afetos e vícios repugnantes, incitando, ao contrário, outros movimentos de alma e virtudes louváveis" (1991 [1739], II, 12, 31, p.207). Neste mesmo passo, Mattheson, emulando a República platônica, fornece um exemplum que confirma a relação: "[...] os sábios espartanos ensinavam a suas crianças o horror à falta de moderação, fazendo dançarem à sua frente escravos bêbados". 24

A despeito das indicações fornecidas, acima, pelos exemplos da prática musical francesa, assim como por Mattheson, a ligação entre ritmo e caráter/virtude, no início do século XVIII, é apenas sugerida. Conforme aponta Videira (2019), só será formalmente declarada por Gottfried Körner, no fim do século XVIII.

A despeito da brevidade da discussão sobre a mensuração em "Sobre a invenção melódica" (restrita a um único inciso), a passagem ganha maior dimensão quando contextualizada no âmbito dos capítulos II, 6 ("sobre a rhythmopoeia"), II, 7 ("sobre a rhy-

23 Original: "Denn es hat keine Melodie die Krafft, eine wahre Empfindung, oder ein rechtes Gefühl bey uns zu erwecken; falls nicht die Rhytmic Bewegung der Klang-Füsse dergestalt anordnet, dass sie einen gewissen wolgefälligen Verhalt mit und gegen einander bekommen".

24 Original: "Fällt mir ein, dass die klugen Spartanern, damit sie ihren Kinderneinen Abscheu vor der Unmässigkeit beybrächten, bisweilen lauter trunkene Sclavenvor ihren Augen tanzen und jauchtzen liessen". 
thmica") e II, 12 ("sobre as especificidades das melodiais vocais e instrumentais") de "O mestre de capela perfeito" (1739), e, ainda, no âmbito do capítulo I, 3 ("sobre os compassos") de "A Orquestra recém-inaugurada" (1713).

O tema (thema) é considerado por Mattheson como a mais importante dentre as três partes da invenção. Ele corresponde à matéria do discurso musical. A julgar pela maneira como Mattheson se refere ao "thema ou frase principal", não há, para ele, distinção entre o entendimento do tema como matéria da composição e seu emprego funcional como frase principal. ${ }^{25}$ Este entendimento sinônimo fica claro tanto em outras passagens do texto de Mattheson (por exemplo, no prefácio de "O mestre de capela perfeito") quanto no verbete "invenção" do dicionário musical de Heinrich Christoph Koch: "Frase principal ou tema é a frase melódica de uma peça musical, que apresenta o caráter principal da emoção a ser representada em um quadro ou impressão compreensível"26 (2001 [1801], p.745).

Para Mattheson, o tema é, portanto, uma frase musical sujeita aos processos de desenvolvimento que resultarão na composição musical. Esta é exatamente a acepção apresentada no dicionário de Johann Gottfried Walther (1732): o tema é "uma frase que gera uma fuga ou outra elaboração"27 (WALTHER, 2001 [1732], p.549).

No capítulo sobre a invenção, Mattheson propõe a obtenção de ideias composicionais a partir de uma coleção preexistente de lugares-comuns: "melodias, procedimentos, cadências e movimentos genéricos" engenhosamente justapostos e aplicados à composição de obras singulares. Nos incisos restantes do capítulo "Sobre a invenção melódica" (21 a 85), Mattheson apresenta quinze lugares-comuns diretamente transferidos de preceptivas poéticas a esta fase inicial do processo de composição.

Ao reconhecer o tema ou frase principal como a matéria, ou seja, a substância essencial da música, Mattheson reconhece a primazia da melodia na invenção musical. Nesse reconhecimento, fica entendido que o modo e a mensuração agem como acidentes do tema, que constitui a matéria principal da composição (MATTHESON, 1991 [1739], II, 4, 20, p.123).

\section{Lugar-comum}

Após apresentar as partes da invenção, o capítulo II, 4 de "O mestre de capela perfeito" é especificamente dedicado ao seu aspecto principal: o tema ou frase principal. Nesse ponto do texto, Mattheson introduz a ideia de lugar-comum, que transpõe da oratória para a música, seguindo e discutindo o procedimento já anteriormente adotado por Johann David Heinichen, em um texto sobre a composição musical (1728).

\footnotetext{
25 Agradecemos, a este respeito, a observação de Barros (2020) sobre uma diferença epistemológica implícita entre os termos, considerando que, apesar da identidade proposta por Mattheson, a ideia de "tema" indicaria o limite ou balizador da matéria, ressaltando a relação entre compositor e receptor, ao passo que "frase principal" apontaria, de modo diverso, para a relação hierárquica de superioridade em relação aos demais elementos empregados na criação da obra, colocando em evidência o ato criativo por seu aspecto mecânico e gramatical.

26 Original: "Hauptsatz oder Thema, ist derjenige melodische Satz eines Tonstückes, der den Hauptcharakter desselben anzudrückende Empfindung in einem fasslichen Bilde oder Abdrucke darstellet".
} 
Em De oratore Cícero já afirma que as causas concretas podem ser reduzidas a um número consideravelmente menor de causas abstratas. Para Cícero, o resumo da variedade de casos a um número mais restrito de substâncias pressupõe, como faz Mattheson, o reconhecimento das matérias essenciais e sua predicação pelos acidentes.

Desde Aristóteles, essas causas genéricas foram reunidas em "lugares-comuns" ou, como descreve Cícero, "sedes, e por assim dizer, moradas de todos os argumentos". Tanto o termo grego topos quanto o latino locus utilizam os lugares físicos como metáfora para indicar categorias mentais. O termo loci topici, utilizado por Mattheson, é um pleonasmo macarrônico (que combina duas línguas) surgido no fim do século XVI.

$\mathrm{Na}$ Grande e completa enciclopédia universal de todas as ciências e artes (Grosses vollständiges Universal-Lexicon aller Wissenschaften und Künste, Halle e Leipzig 17311754), editada por Johann Heinrich Zedler, lemos que

Loci Topici são certos compartimentos ou receptáculos onde se encontram argumentos que pertencem à Tópica. Pois Locus significa, entre outros, entre os antigos, uma prova ou uma sede de um argumento [...] e a Tópica era aquela parte da Lógica que ensinava a inventar os argumentos. ${ }^{28}$ (ZEDLER, 1731-1754, v.18, col.104-105).

O dicionário português de Raphael Bluteau (1712-1728) pronuncia, de modo semeIhante, que "lugares communs da rhetorica são as fontes dos argumentos, \& as circunstancias donde se tomão as provas nos discursos Oratorios" (BLUTEAU, 1716, v.5, p.201).

Christian Friedrich Hunold, cuja poética Mattheson certamente conheceu, também afirma:

$\mathrm{Na}$ invenção do tema recomendo novamente assuntos específicos [Specialia], que o próprio poeta deve ter em seu estoque. Contudo, nada pode ser tão específico que não possa ser contido em uma classe de assuntos genéricos [Generalium], e os assuntos genéricos [...] indicam, no mínimo, o caminho pelo qual, meditando, se chega aos assuntos específicos [Specialibus], como já se entende. E estes são, em uma palavra, os Loci Topici. ${ }^{29}$ (HUNOLD, 1722 [1709], VI, 5 e 6, p.542).

Sendo assim, lugares-comuns são argumentos que agrupam, em conjuntos genéricos, a variedade de argumentos que pertencem aos casos específicos.

Mattheson não apresenta uma definição sistemática dos Loci topici, entretanto ela aparece na preceptiva musical de Meinrad Spiess, Tractatus Musico-Practicus (1745), que cita extensas passagens de "O mestre de capela perfeito": "Tópica ou topice é uma

28 Original: "Loci Topici heissen gewisse Fächer, oder Behältnisse, darinn man Beweisgründe antrifft, die zur Topic gehören. Denn Locus heisst unter andern bey den Alten ein Beweis, oder ein Sitz eines Beweisthums [...], und die Topic war derjenige Theil der Logic, welcher zur Erfindung der Beweisthümer Anleitung gab".

29 Original: "Bey der Inventione Thematis recommendiere ich abermahl Specialia, welche der Poete selbst im Vorrathe haben muss. Doch kann nichts so special seyn, es kan unter eine Classe der Generalium gebracht werden. Und die Generalia, welche in diesem Capitel gewiesen werden, geben mir zum wenigsten den Weg an die Hand, wodurch ich Meditando zu den Specialibus gelangen kan, wie schon itzt gedacht ist. (6) Und das sind nun mit einem Worte die Loci Topici". 
arte de inventar argumentos ou provas; com isso, Loci Topici são a sede e os meios de onde se tiram as invenções"30 (1745, XXV, p.133).

Mattheson explica o processo: "[...] specialia ad generalia ducenda, como dizem os oradores" (1991 [1739]. II, 4, 17, p.123).

Cícero afirma que os lugares-comuns constituem um repositório ou "sedes de argumentos" (sedes argumentorum) pertencentes sobretudo ao domínio da memória. Como diz Mattheson, é uma coleção constantemente enriquecida "pela escuta atenta de boas obras" e sujeita a constante modificação, não se referindo a uma catalogação física sistemática, da mesma maneira que o domínio do vocabulário e da matéria são signos do falar bem:

Com efeito, não precisamos, cada vez que temos de escrever uma palavra, buscar em nosso pensamento as letras de tal palavra; nem, cada vez que é preciso defender uma causa, é preciso que recordemos os argumentos específicos de tal causa, mas que tenhamos à mão determinados tópicos que, tal como acontece nas letras, quando escrevemos uma palavra, ocorram-nos imediatamente para a explicação da causa. ${ }^{31}$ (CÍCERO, 2009 [46 a.C.], II, 130, p.218, tradução: A. Scatolin).

Ao transpor a ideia de lugares-comuns da oratória para a música, Mattheson indica, como matérias essenciais da composição, procedimentos codificados, tais como cadências, movimentos harmônicos, cantos e saltos melódicos. Mattheson dá alguns exemplos de lugares genéricos e mostra sua aplicação na constituição de uma frase musical:

Se, por exemplo, eu tivesse em mente estes três caminhos melódicos diversos e independentes
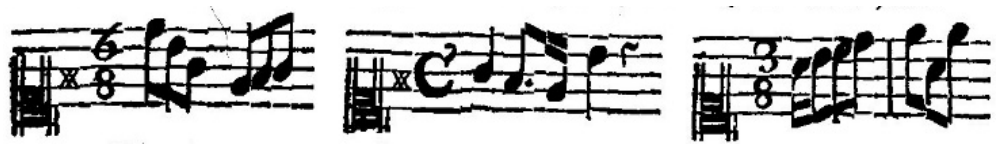

e quisesse, a partir dos mesmos, constituir uma frase completa, ela poderia ter a seguinte aparência:

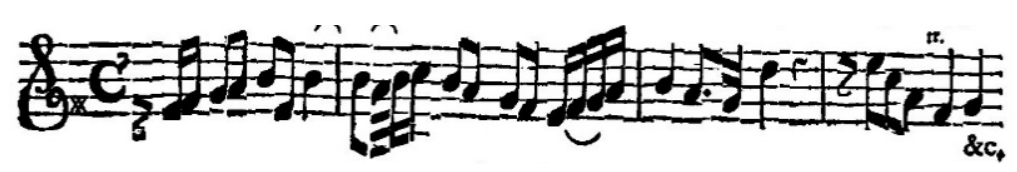

Figs. 2 e 3: incisos e frase musical. Fonte: Mattheson (1991 [1739], II, 4, 15, p.127).

Sabemos que o aprendizado musical setecentista, realizado a partir do baixo contínuo, é formulado a partir do preceito, exemplo e imitação, e pressupõe o aprendizado de uma série de fórmulas harmônicas genéricas: Romanesca, Follia, Ciaconna etc., as-

\footnotetext{
30 Original: "Topica oder Topice heisst eine Kunst, argumenta oder Beweys-Gründe zu erfinden; dahero, Loci topici seynd der Sitz, und die Mittel, woraus die Erfindungen herzunehmen".

31 Original: "Neque enim, quotiens verbum aliquod est scribendum nobis, totens eius verbi litterae sunt cogiagione conquirendae; nec quotiens causa dicenda est, totens ad eius causae seposita argumenta revolvi nos oportet, sed habere certos locos, qui, ut litterae ad verbum scribendum, sic illi ad causam explicandam statim occurrant".
} 
sim como o emprego de intervalos musicais, conduções harmônicas etc. que constituem uma série de procedimentos musicais codificados.

O aprendizado proporciona o domínio desses modelos, levando à criação de um repositório de fórmulas que permite a construção de novas peças. É fácil compreender que, assim como na oratória, a enorme variedade de lugares-comuns musicais não seria passível de uma catalogação sistemática completa. O próprio Mattheson (1991 [1739], II, 4, 18, p.123) afirma: "[...] sempre é possível adquirir uma coleção escrita na qual se apresentem todos os bons caminhos melódicos e cantos agradáveis, organizada segundo capítulos e incisos, que, caso necessário, ofereça conselho e consolo". ${ }^{32}$

O fornecimento de regras e modelos é tarefa das preceptivas, que, obviamente, não se propõem a esgotar os assuntos. Lemos, por exemplo, em Burmeister:

Mesmo que a natureza, a imitação e o exercício não levem ao cume das coisas tratadas neste manual, sem os testemunhos da obra de arte; mesmo que faltem as regras, que são ao meu ver o intuito deste livrinho; e mesmo que aquilo que é abordado não possa ser alcançado sem o auxílio de certas regras, não se pode encontrar auxílios completos em um manual. ${ }^{33}$ (BURMEISTER, 2004 [1606], s.p., tradução minha).

A tratadística oferece os preceitos e alguns exemplos, porém, só a experiência permite a ampliação do catálogo de lugares-comuns. Contudo, a aplicação artificiosa dos mesmos é fruto do engenho. Neste sentido, o critério romântico de originalidade não é um parâmetro norteador da composição.

Finalmente, Mattheson reconhece ainda a possibilidade de trilhar o caminho inverso, provendo uma aplicação de cláusulas genéricas a composições específicas, mediante um emprego "especial" de lugares-comuns. O exemplo que ele fornece é o da cadência que, sendo genericamente empregada como artifício finalizante, pode engenhosamente ser utilizada como recurso inicial. Embora Mattheson não forneça exemplos musicais, a ideia pode ser ilustrada pelos trechos abaixo, sendo o primeiro extraído da Sonata op. 5/1 de Arcangelo Corelli (1700), que inicia com uma fórmula cadencial.

\footnotetext{
32 Original: "Zwar wem es anstehet, und den die Noth dazu treibet, der mag sich immerhin eine solche schrifftliche Sammlung anschaffen, worin alles, was ihm etwa hie und da an seinen Gängen und Modulirungen auffstösst oder gefällt, ordentlich unter gewisse Haunpt-Stücke und Titel zu finden seyn, damit er, efordernden Falls, Rath und Trost daraus holen könne".

33 Original: "Dum ne natura, imitatio, \& exerciciartio ad fastigia rerum, quae in Arte tractantur, sine artificii documentis contendere possint; imone id, in quo compendij illius rationem consistere arbitrer, praeceptionibus careat, imo etjam, quod in arte minimum est, de quo institutio sascipitur, nisi formatio excertis de eo paeceptis sumantur, non percipi, ita nec artis presidia quisqum habere possit perfecta.unde hoc consequenter necessum sit, ut Arsi, si ejus aliqua pars praetermittitur, integre non communicetur; aut certè si preceptis necessarijs locum non dmus, nec ea cognoscere volumus, non plene precipiantur, \& non leve vel invidenirae, vel socordiae signum subbit".
} 


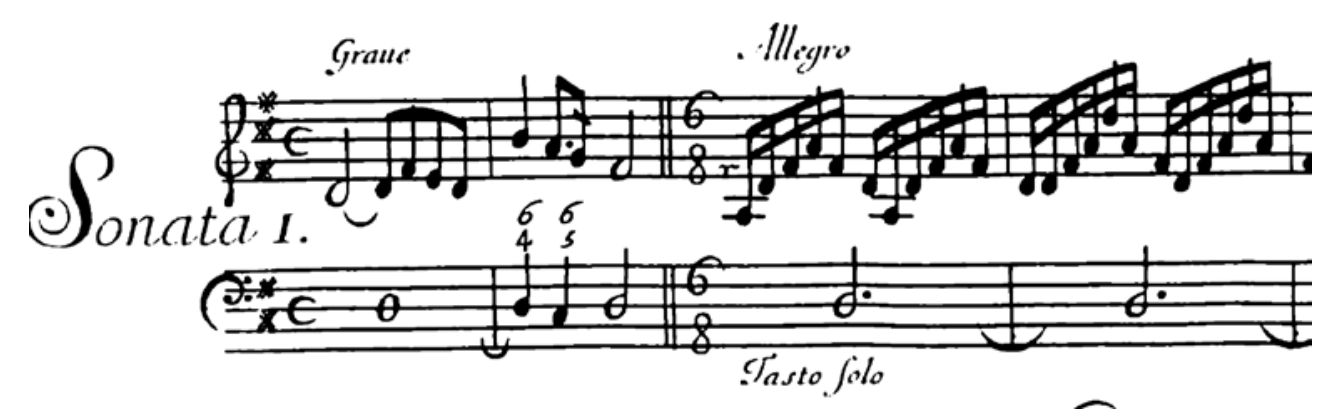

Fig. 3: Sonata op. 5/1/I, compassos 1-4. Fonte: Corelli (s.d. [1700] apud LAGR, 2019).

O segundo, da pena de Joseph Haydn, também faz uso engenhoso da cadência como recurso inicial da invenção.

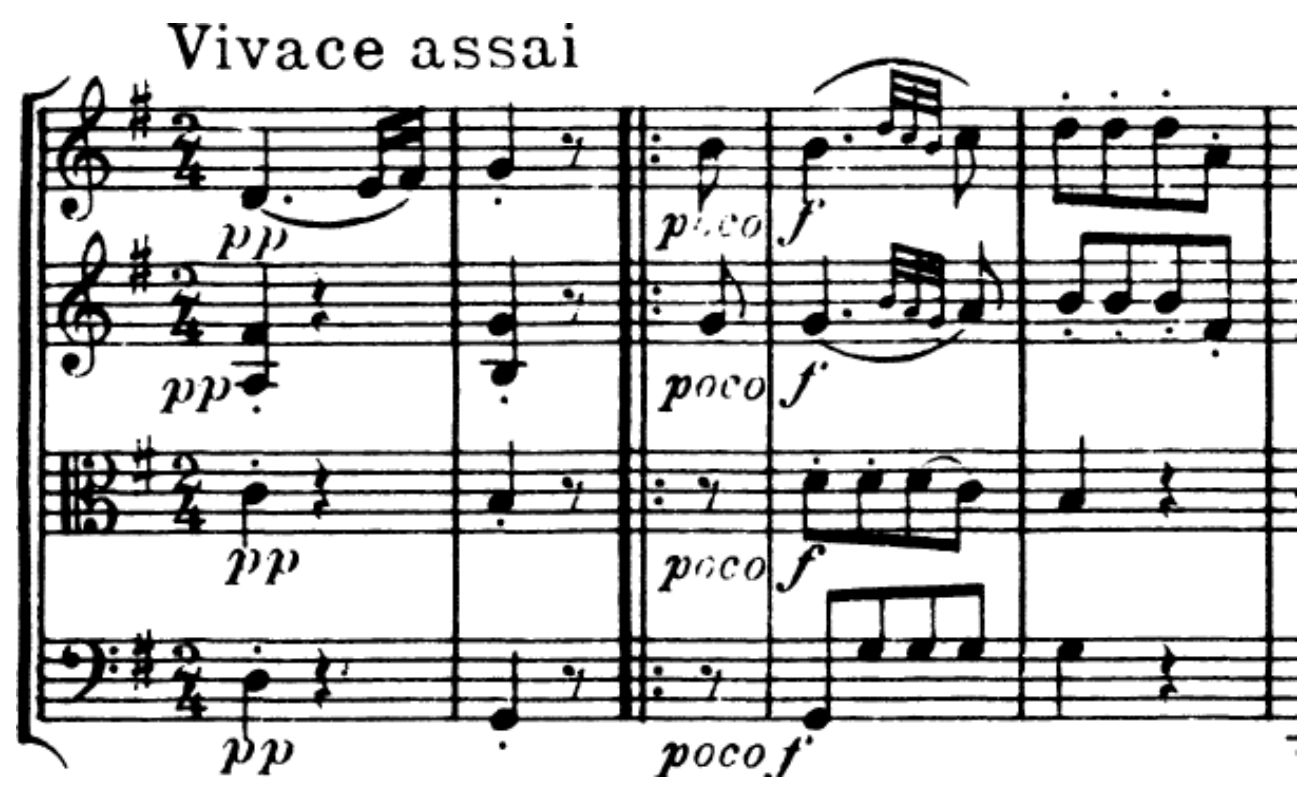

Fig. 4. Quarteto de cordas op. 33/5/I (1782), compassos 1-4. Fonte: Haydn (1960).

Mattheson dedica a maior parte do capítulo sobre a invenção melódica de "O mestre de capela perfeito" à descrição e explicação de 15 lugares-comuns para a invenção melódica (70, dentre os 85 incisos que compõem o capítulo). Curiosamente, ele afirma que os mesmos possuem utilidade apenas parcial: "Os loci topici podem às vezes (apesar de eu não dar grande importância aos mesmos) fornecer auxílios bastante sensatos para a invenção, tanto na composição melódica, quanto na poesia e na oratória" 34 (MATTHESON, 1991 [1739], II, 4, 20, p.128). Esta afirmação tem sido bastante discutida por leitores de Mattheson, como Arlt (1983).

Nos incisos 21 a 24 de "Sobre a invenção melódica", Mattheson remete o leitor a três textos que amparam sua discussão sobre lugares-comuns: o já mencionado "O baixo-contínuo na composição" (Der General-Bass in der Composition, 1728) de Johann Heinichen, "Preparação para a prova do organista" (Vorbereitung zur Orga-

34 Original: "Die bekannten loci topici (ob ich gleich selbst, meines Orts, keinen grossen Staat darauf mache) [können] bisweilen ziemlich artige Hülffs-Mittel zum Erfinden, eben sowol in der melodischen Setz-Kunst, als im Dichten und Reden, an die Hand geben". 
nistenprobe, 1719) da autoria do próprio Mattheson e "Introdução completa à oratória alemã e latina" (Gründliche Einleitung zur Teutschen und Lateinischen Oratorie, 1717), de Christoph Weissenborn.

A extensa introdução a "O baixo-contínuo na composição" de Heinichen consiste na única transposição dos lugares-comuns da oratória para invenção musical anterior àquela proposta em "O mestre de capela perfeito". Entre as páginas 30 e 88, Heinichen, embora não forneça uma definição clara de lugar-comum, discute sua utilidade na composição musical e escreve:

Com certeza, metade do trabalho para encontrar a invenção se dá quando o compositor consegue fazer uma boa ideia do texto (às vezes totalmente infrutífero) que tem diante de si. No entanto, penso que não é possível conduzir os pensamentos a boas ideias e avivar a fantasia natural de maneira melhor do que através dos Locos Topicos da oratória. É preciso apenas examinar, mesmo nas matérias mais infrutíferas, 3 fontes principais, a saber Antecedentia, Concomitantia, \& Consequentia Textus a partir dos Locis Topicis e considerar a ocasião das palavras e as circunstâncias que nelas concorrem - pessoa, matéria, essência, causa, modo e maneira, finalidade, o tempo, o lugar etc. Assim não faltarão ideias agradáveis - ou para ser mais claros, inventionibus adequadas - à expressão daquele que tem fantasia natural boa e inata (pois não tratamos dos ingeniis stupidis). ${ }^{35}$ (HEINICHEN, 1994 [1728], p.30).

Heinichen, como Mattheson, afirma a utilidade dos lugares-comuns, especialmente quando o texto não provê o compositor com boas ideias.

A segunda obra indicada por Mattheson, "Preparação para a prova do organista" (1719), de sua própria autoria, traz uma informação curiosa e que remete unicamente ao uso de lugares-comuns em uma discussão de caráter retórico.

"No baixo-continuo, o organista não pode tropeçar sem causar vexame" [...] são palavras que oportunamente dariam um bom texto, se as dividirmos em 4 partes e tudo e as anatomizarmos de maneira escolar de acordo com o quis, quid, ubi, quibus auxiliis, cur, quomodo, quando. Pois com isto examinaríamos, em primeiro lugar, o organista de acordo com todos seus requisitis \& praedicatis; em segundo, o baixo-continuo; em terceiro, o tropeço; e, em quarto, do vexame decorrente do mesmo. ${ }^{36}$ (MATTHESON, 1719, p.1).

Neste texto, o que está sendo analisado com auxílio dos lugares-comuns é uma asserção retórica sobre a qualificação do organista, e não a matéria musical. A utilidade

\footnotetext{
35 Original: "Gewiss dass es halbe Müh sey / Invention zu finden/ wenn sich der Componist eine gute Idee von den ihm vorgelegten (zuweilen ganz unfruchtbahren) Texte machen kan. Unsere Gedencken aber auff gute Ideen zu leiten / und die natürliche Fantasie aufzumuntern / solches kan meines erachetens nichtbesser geschehen / als durch die Oratorischen Locos Topicos. Man mag auch bey denen allerunfruchtbahresten Materien nur 3 fontes principales, nehmlich Antecedentia, Concomitantia, \& Consequentia Textus nach denen Locis Topicis examiniren / und occasione der Worte / die dabey concurrirenden Umstände der Person / der Scahe / des Wesens / des Urspprungs / der Arth und Weise / des Entzweckes / der Zeit / des Ortes u. wohl erweggen, so wird es der angebohren guten natürlichen Fantasie (von ingeniis stupidis reden wir nicht) niemahls an Expression beliebter Ideen, oder deutlicher zu reden: an geschickten Inventionibus fehlen".
}

36 Original: "Im Basso Continuo darf kein Organiste ohne Schande stolpern [...] sind Worte die bey diesem Gelegenheit einen sehr guten Text abgeben könnten wen man vier Theile daraus machen und alles nach dem: quis, quid, ubi quibus auxiliis, cur quomodo, quando, Schulfüchtschich anatomiren wollte. Denn da wäre erstlich der Organiste nach allen seinen Requisitis \& Praedicatis; vors andre der Basso Continuo; drittens das Stolpern; und vierdtens, die daraus entspringende Schande wohl zu betrachten". 
do texto para considerar a invenção musical pode residir no auxílio que a passagem fornece para compreender o processo de obtenção de argumentos inventivos na argumentação sobre uma afirmação verossímil, e, portanto, de caráter retórico ("erros na realização do baixo contínuo levam ao vexame"). Mattheson observa, contudo, que os lugares apresentados nesse texto - quis, quid, ubi, quibus auxiliis, cur, quomodo, quando - são lugares dialéticos, e não retóricos. Com isto, ele parece apontar para a ideia de que seja possível tratar da matéria musical a partir de considerações retóricas, à maneira do que ocorre com a palavra. Os lugares-comuns retóricos que ele apresentará em seu texto de 1739 são, no entanto, diversos dos apresentados no texto de 1719.

Com relação à terceira referência, "Introdução completa à oratória alemã e latina" (1717), Christoph Weissenborn, ao discorrer sobre a invenção de argumentos discursivos, apresenta - embora sem fornecer nenhum detalhamento ou inserir exemplos - uma lista de 11 lugares-comuns, a saber: Locus 1. Notationis; 2. Definitionis; 3. Totius \& Partium; 4. Generis \& Speciei; 5. Causarum; 6. Effectorum; 7. Adjunctorum; 8. Contrariorum (que Mattheson denomina Oppositorum); 9. Comparatorum; 10. Exemplorum; 11. Testimoniorum (WEISSENBORN, 1717, II, I, 164, p.223). Uma comparação entre estes lugares e aqueles apresentados por Mattheson evidencia que em Weissenborn falta o lugar-comum da circunstância (circumstantiarum) exposto em Mattheson, sendo a lista, no restante, idêntica. Para maior detalhamento sobre o assunto, Weissenborn remete o leitor à leitura de livros de Lógica.

Selecionamos, desta forma, como referência adicional, as "Questões curiosas sobre a lógica" (Curieuse Fragen über die Logica, Leipzig, 1696) de Christian Weise, obra de enorme circulação no mundo reformado e que certamente serviu de modelo direto ou indireto à maioria das categorizações apresentadas em retóricas e poéticas germânicas setecentistas. Os lugares apresentados por Weise, diversamente do que ocorre em Weissenborn e em Mattheson, são logicamente organizados (I, VI, 3, p.201). Esta sistematização fornece uma chave interessante para a compreensão do texto de Mattheson. Segundo Weise, 
[Quando] observamos

O nome da coisa

A coisa em si

a. Em sua totalidade

b. Em partes

b.1. internas (refere-se a coisa em si)

Causae (efficiens, materialis, formalis, finalis)

Effectus

Circumstantiae

Adjuncta

b.2. externas (comparação externa com a coisa)

(WEISE, 1696, I, VI, 3, p.201, tradução minha).
Este é o lugar

Notationis

Definitionis, Descriptionis

Genus \& Species

Totum \& Pars

Comparata

Opposita

Exempla

Testimonia $^{37}$

Tattlow (1991) aventa, embora sem fundamentação definitiva, que os lugares-comuns apresentados por Mattheson estão baseados em "A nova maneira de lograr a poesia pura e galante" (Die Allerneueste Art zur reinen und galanten Poesie zu gelangen, 1722), de Christian Friedrich Hunold.

De fato, Hunold apresenta uma lista de lugares-comuns idêntica às de Mattheson e Weise, e sabidamente frequentou os mesmos círculos que Mattheson em Hamburgo entre 1700 e 1706, tendo também publicado a obra mencionada por Tattler ("A nova maneira de lograr a poesia pura e galante"), em Hamburgo (1722). Contudo, considerando a ampla circulação de Weise e o conhecido fato de que sistematização de Weise foi reproduzida em muitas poéticas setecentistas, a hipótese de que tenha servido como referência direta para Mattheson não deve ser desconsiderada. No entanto, os exemplos fornecidos por Hunold são muito úteis para a compreensão dos lugares-comuns em Mattheson.

Com relação à importância da Topica para a composição musical, Mattheson se pronuncia, em "O mestre de capela perfeito": "[...] o texto a seguir vai convencer [eventuais opositores] que isto não apenas pode acontecer de maneira totalmente natural, mas ainda que isto de fato deve acontecer necessariamente desta maneira na doutrina

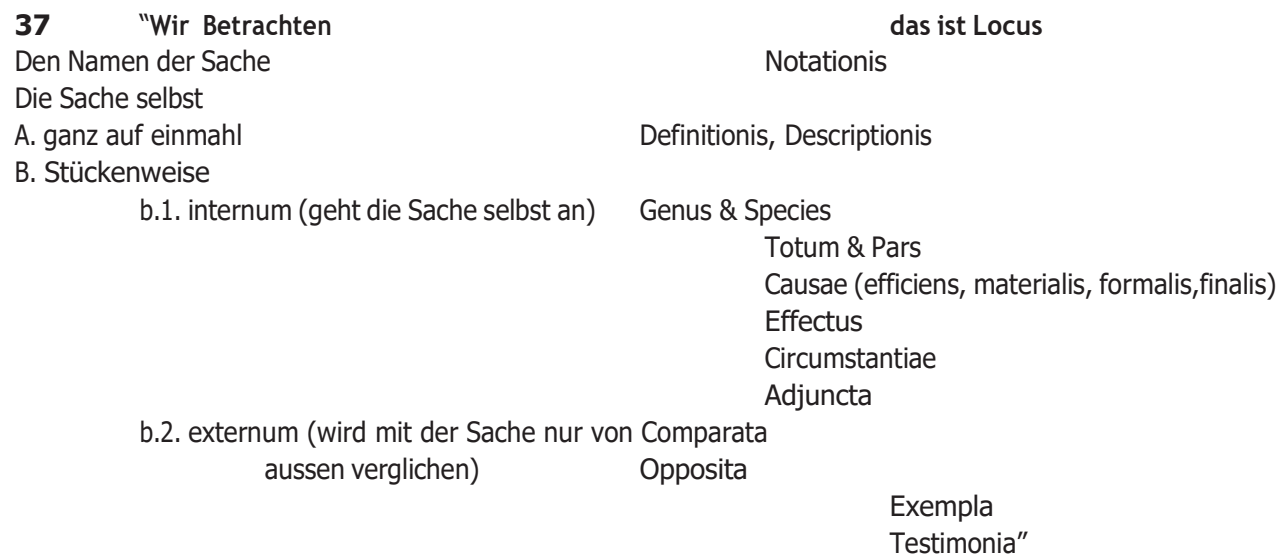


da invenção"38 (1991 [1739], II, 4, 24, p.124), a despeito de o assunto não haver sido devidamente sistematizado à época de Mattheson.

Ainda com relação às possibilidades de transposição dos lugares-comuns da oratória para a música, vale lembrar que, apesar de Mattheson seguir a ordem proposta por Weise e Hunold, a sistematização dos lugares na oratória e na música assume naturalmente outro sentido, pela própria relação mais aberta entre signo e significado na linguagem musical.

O texto sobre os lugares-comuns na invenção melódica em Johann Mattheson mostra como a criação de temas pode se basear em codificações advindas da própria escrita musical, a partir de técnicas do contraponto (lugar da notação), do número e qualidade das vozes (lugar do todo-parte), do tipo de escrita (lugar do gênero-espécie) e do uso das consonâncias e dissonâncias (lugar da causa material). Ao abordar questões externas, os temas podem ser concebidos a partir da representação mecânica de paixões (lugar da descrição), do texto (lugar da causa eficiente), das qualidades específicas de um intérprete (lugar da causa formal), do caráter ou circunstâncias de um objeto (lugar dos adjuntos), da comparação (lugar da comparação), do contraste (lugar da oposição), da imitação de um modelo (lugar dos exemplos) ou da citação de outra obra (lugar dos testemunhos); com relação à recepção, temas musicais podem ser concebidos levando em consideração a finalidade (lugar da causa final), as circunstâncias (lugar das circunstâncias) ou o efeito (lugar dos efeitos). A consideração de todos estes aspectos resultará em temas adequados à situação, ao tempo, ao lugar e à circunstância, de modo que, ao mover o ouvinte, cumpram com a finalidade edificante da música.

\section{Conclusão}

Uma vez que a natureza não se sustenta por si, Mattheson discute a necessidade da sistematização das etapas da composição musical que são detalhadas no próprio capítulo sobre a invenção, assim como no restante das partes II e III de "O mestre de capela perfeito". Inventio, no sentido técnico da retórica, é a denominação dada à primeira etapa da construção do discurso. Ela se concentra no achamento dos pensamentos e das possibilidades argumentativas a serem desenvolvidas a partir de um tema ou de uma questão. Refere-se, assim, à apreciação das circunstâncias que se relacionam à matéria tratada. A etapa da inventio visa obter uma visão geral dos assuntos com vistas à argumentação. Na música, visa à elaboração de um tema ou frase principal.

Mattheson divide a invenção musical em três partes: tema (thema), modo (modus) e mensuração (tactus). Ao passo que tema e modo se relacionam respectivamente àquilo que, nos manuais retóricos, constituem respectivamente a matéria e o afeto, a relação entre a mensuração e o caráter, o terceiro elemento persuasivo das retóricas gre-

38 Original: "Ob nun gleich mancher dencken dürffte, es würde grossen Zwang erfordern, alle diese Dinge zur musicalischen Setz-Kunst hinzuziehen; so wird doch die Folge einen ieden überführen, dass solches nicht nur ganz natürlicher Weise geschehen könne, sondern dass es auch in der That bey der Erfindungs-Lehre so seyn müsste: ungeachtet es noch von niemand ordentlich versuchet worden, noch auch ein ieder dialectischer locus eben mit gleicher Geschicklichteit und Wichtigkeit dazu versehen ist". 
co-latinas, apresenta-se apenas sugerida. Neste sentido, Mattheson parece prefigurar uma afirmação que só será formalmente declarada no século XIX por Gottfried Körner.

Após descrever as partes da invenção, Mattheson, em "Sobre a invenção melódica”, concentra-se na invenção temática (thema). Na música, Mattheson afirma que esta é a etapa que resultará na composição da frase ou tema principal. Ele elenca uma série de 15 lugares-comuns, sedes de argumentos úteis para a composição musical, levando em conta elementos internos e externos.

A invenção de discursos a partir de lugares-comuns faz parte da arte retórica desde Aristóteles. No mundo humanista, a discussão ciceroniana, mais do que a aristotélica, é a base para discussões humanistas. Poéticas e retóricas seiscentistas italianas e espanholas circularam na Alemanha e geraram imitações que floresceram especialmente em Leipzig e em sua vizinhança. Entre elas encontram-se a retórica de Christoph Weissenborn (único autor citado por Mattheson), além de Christian Weise e Christian Friedrich Hunold, autores que decerto serviram como modelos para Mattheson.

A despeito de quem seja o modelo real de Mattheson, interessa saber que a composição literária a partir de lugares-comuns é prática sistematicamente descrita em Retóricas gregas, latinas e humanistas. O que importa não é tanto a genealogia das discussões sobre lugares-comuns, ou as semelhanças e diferenças entre elas, mas o fato de que todos esses autores, inclusive Mattheson, conduzem suas reflexões em termos retóricos.

Autores como Arlt (1983) defendem a opinião de que a exposição de Mattheson a respeito de lugares-comuns constitua antes uma prova de erudição pedante, com base na passagem acima mencionada de "Sobre a invenção melódica" em que Mattheson afirma de passagem não creditar grande importância aos lugares-comuns (II, 4, 20, p.123). Entretanto, esta afirmação contrasta tanto com a declaração do mesmo autor, de que a transposição dos lugares-comuns seja natural e até mesmo necessária (II, 4, 24 , p. 124), quanto com a própria extensão da explicação sobre os lugares comuns, que domina a maior parte do capítulo (70, dentre os 85 incisos).

Ao discordar de autores como Arlt, entendemos que a visita a lugares-comuns certamente constituiu um guia eficaz para a composição musical nos séculos XVII e XVIII. Todos os lugares apresentados por Mattheson visam à construção de temas que respondam às exigências de composições que, diversamente do que passou a ocorrer no século XIX, eram pensadas para ocasiões, tempos, intérpretes e públicos específicos. Estas composições certamente dependiam do conhecimento de lugares como aqueles indicados por Mattheson, ainda que possivelmente os compositores não pensassem da maneira sistemática apresentada em "O mestre de capela perfeito". Além disso, no século XXI, os lugares-comuns podem prover resultados interessantes na análise musical, quando se trilha o caminho que vai, ao inverso do pretendido por Mattheson, da obra pronta aos seus pontos de partida. 


\section{Referências}

ARLT, Wulf. Zur handhabung der inventio in der deutschen Musiklehre des frühen achtzehnten Jahrhunderts. In: BUELOW, George und Hans-Joachim Marx. New Mattheson Studies. Cambridge: Cambridge University Press, 1983. p. 371-391.

BARROS, Cassiano de Almeida. A teoria fraseológico-musical de H.C. Koch (17491816). Tese (Doutorado em Música) - Universidade Estadual de Campinas, Campinas, 2011. Disponível em: http://repositorio.unicamp.br/bitstream/REPOSIP/284457/1/ Barros_CassianodeAlmeida_D.pdf. Acesso em: 31 out. 2018.

BLUTEAU, Raphael. Vocabulario Portuguez \& Latino (1712-1728). Coimbra: Collegio das Artes da Companhia de Jesu, 1712-1728. 8 v. Disponível em: http://www.ieb.usp.br/ online/index.asp. Acesso em: 23 jan. 2019.

BROSSARD, Sebastién de. Dictionnaire de Musique. Amsterdam: Estienne Roger, c.1708. Disponível em: https://imslp.org/wiki/Dictionnaire_de_musique_ (Brossard\%2C_S\%C3\%A9bastien_de). Acesso em: 23 nov. 2019.

BURMEISTER, Joachim. Musica Poetica (Rostock, 1606). Laaber: Laaber, 2004.

CÍCERO, Marco Túlio. De Inventione. London: Harvard University Press, 1949 [87 a.C.] (Loeb Classical Library).

CÍCERO, Marco Túlio. De Oratore. London: Harvard University Press, 1942 (Loeb Classical Library).

CíCERO, Marco Túlio. Do Orador. In: SCATOLIN, Adriano. A invenção no Do Orador de Cícero: um estudo à luz de Ad familiares, I, 9, 23. Tese (Doutorado em Letras) Universidade de SãoPaulo, São Paulo, 2009. Disponível em https://www.teses.usp.br/ teses/disponiveis/8/8143/tde-19022010-165443/pt-br.php . Acesso em: 23. Nov. 2019

[CíCERO]. Retórica a Herênio [Rhetorica ad Herennium]. São Paulo: Hedra, 1995. Disponível em: http://imslp.eu/files/imglnks/euimg/f/fd/IMSLP484218-PMLP24942711_56aa-PMLP12576-Dietrich_Buxtehude_-_S\%C3\%A4mtliche_Orgelwerke_(Hedar), Vol._4_(music_only),_as_scanned.pdf. Acesso em: 6 out. 2019.

CORELLI, Arcangelo. Sonata op. 5 n. 1. Rome: Gasparo Pietra Santa, s.d. [1700]. Disponível em: http://conquest.imslp.info/files/imglnks/usimg/3/3a/IMSLP526383PMLP639906-corelli_op5_no1.pdf. Acesso em: 3 maio 2019.

DONI, Giovanni Battista. De praestantia musicae veteris. Florentia: Foroliuien, 1647. 
Disponível em: https://books.google.com.ar/books?id=w-tCAAAAcAAJ\&pg=RA3PP3\&lpg=RA3-PP3\&dq=donius+de+praestantia\&source=bl\&ots=ktSjQEq3Js\&si $g=0$ oeeXuhW81Ow2Hinr8ZFI35GHV8\&hl=pt-BR\&sa=X\&ved=2ahUKEwjYwd7r_ rjeAhUHjJAKHdITA64Q6AEwAnoECAUQAQ\#v=onepage\&q=donius $\% 20$ de $\% 20$ praestantia\&f=false. Acesso em: 2 set. 2018.

DREYFUSS, Laurence. Bach and the Patterns of Invention. Harvard: Harvard University Press, 2004.

HAYDN, Joseph. Quartetos de cordas op. 33. Leipzig: Ernst Eulenburg, 1960.

Disponível em: http://conquest.imslp.info/files/imglnks/usimg/0/01/IMSLP455448-

PMLP12766-Op33_comb.pdf. Acesso em: 30 jan 2019.

HEINICHEN, Johann David. Der Generalbass in der Composition. Laaber [Dresden]:Laaber Verlag [o autor], 2005 [1728].

HILLER, Johann Adam. Kritischer Entwurf einer musikalischen Bibliothek. In: HILLER, Johann Adam. Wöchentliche Nachrichten und Anmerkungen an die Musik betreffend. Leipzig: Verlag der Zeitungs-Expedition, 1768 (4 e 18 jul. 1768). p. 1-7. Disponível em: https://reader.digitale-sammlungen.de/de/fs1/object/display/bsb10271143_00007. html. Acesso em: 12 fev. 2020.

HUNOLD, Christian Friedrich. Die allerneueste Art, zur Reinen und Galanten Poesie zu gelangen. Hamburg: Fickweiler [Liebernickel], 1722 [1709]. Disponível em: https:// reader.digitale-sammlungen.de/de/fs1/object/display/bsb10111718_00005.html. Acesso em: 20 jun. 2018.

INVENÇÃO. In: DICIONÁRIO Caldas Aulete. [S. I.]: Lexicon, [s.d.]. Disponível em: http:// www.aulete.com.br. Acesso em: 30 set. 2018.

KIRCHER, Athanasius. Musurgia Universalis sive Ars magna Consoni et Dissoni. Hildesheim [Roma]: Georg Olms, 1999 [1650].

$\mathrm{KOCH}$, Heinrich Cristoph. Musikalisches Lexikon. Kassel [Frankfurt am Main]: Bärenreiter [August Hermann der Jüngere], 2001.

LUCAS, Monica. O lugar-comum arte-natureza em Der vollkommene Capellmeister [“o mestre-de-capela perfeito", 1739], de Johann Mattheson. Trans-forma-ação, Unesp, v. 39, n. 1, p. 35-72, 2016.

MATTHESON, Johann. Critica Musica. Hamburg: der Author, 1722-1725. Disponível em: https://reader.digitale-sammlungen.de/de/fs1/object/display/bsb10527428_00005. html. Acesso em: 3 nov. 2017. 
MATTHESON, Johann. Das Neu-Eröffnete Orchestre (Hamburg, 1713). Laaber: Laaber Verlag, 2004.

MATTHESON, Johann. Der Vollkommene Capellmeister (Hamburg, 1739). Kassel: Bärenreiter, 1991.

MATTHESON, Johann. Exemplarische Organistenprobe. Hamburg: Schiller und Kissner, 1719. Disponível em: https://reader.digitale-sammlungen.de/de/fs1/object/display/ bsb10527431_00023.html. Acesso em: 2 maio 2018.

QUINTILIANO, Marco Fabio. Instituição Oratória [Institutio Oratoria]. Campinas: Edunicamp, 2015.

RIPA, Cesare. Iconologia or Moral Emblems. London: Tempest, 1709. Disponível em: http://dinamico2.unibg.it/ripa-iconologia/edizioni.html\#ed_18. Acesso em: 2 jul. 2018.

SCHEIBE, Adolf. Der Critische Musicus. Hamburg: Beneke, 1738. Disponível em: https://reader.digitale-sammlungen.de/resolve/display/bsb10599388.html. Acesso em: 23 maio 2018.

SARAIVA, Francisco Rodrigues dos Santos. Novíssimo Dicionário Latino Português. São Paulo [Le Havre]: Garnier/Martins Fontes [Garnier], 2000 [1881].

SPIESS, Meinad. Tractatus Musico-Practicus. Augsburg: Johann Grossens Erben, 1745. Disponível em: https://ims/p.org/wiki/Tractatus_Musicus\%2C_Op.8_ (Spie\%C3\%9F\%2C_Meinrad). Acesso em: 2 ago. 2019.

STEBLIN, Rita. A History of Key Characteristics in the 18th and Early 19th Centuries. Rochester: University of Rochester Press, 2005 [1983].

TATLOW, Ruth. Bach and the riddle of the number alphabet. Cambridge: Cambridge Universtity Press, 1991.

VIDEIRA, Mário Rodrigues. Schiller, Körner e a questão da estética musical. In: SILVA, F. M. F.; MARQUES, U. R. de A. (org.). Arte \& Filosofia. Lisboa: Centro de Filosofia da Universidade de Lisboa, 2019. p. 97-117.

WEISE, Christian. Curieuse Fragen über die Logica. Leipzig: Johann Grossens Erben, 1696. 
WEISSENBORN, Christoph. Gründliche Einleitung zur Teutschen und Lateinischen Oratorie. Frankfurt und Leipzig: Christian Pohl, 1713. Disponível em: http://reader. digitale-sammlungen.de/de/fs1/object/display/bsb11081452_00005.html. Acesso em: 5 ago. 2019.

ZEDLER, Johann Heinrich. Grosses vollständiges Universal-Lexikon. Leipzig: der Author, 1731-1754. Disponível em: http://www.zedler-lexikon.de/. Acesso em: 15 set. 2018. 